\title{
The 'new paradigm' of outcomes-based education in perspective
}

\author{
SPT Malan
}

\section{OPSOMMING}

Uitkomsgebaseerde onderwys (UGO) word deur sommige as ' $n$ paradigmaskuif in die onderwys gepropageer. Die doel van die artikel is om hierdie aanspraak toe te lig teen die agtergrond van veral vier onderrig- en leerbenaderings, naamlik doelwitgerigte onderrig, bevoegdheidsgebaseerde leer, bemeesteringsleer, en kriteriumgerigte onderrig en assessering.

Teen die agtergrond van die voorgemelde benaderings word getoon dat UGO nie ' $n$ paradigmaskuif meebring nie. UGO kan ten beste beskryf word as ' $n$ eklektiese onderwysfilosofie wat op die beste elemente in hierdie onderwysbenaderings berus. Ooreenkomstig die behoeftes en eise wat aan 'n nuwe demokratiese Suid-Afrika gestel word, is die elemente egter in 'n visioenêre raamwerk saamgevoeg om aan die land se mensekragbehoeftes en werkvereis tes te voldoen.

Daar is ook voordele aan UGO verbonde. Die belangrikste hiervan is die nasionale fokus op onderwys as ' $n$ middel tot ' $n$ doel en nie ' $n$ doel op sigself nie. ' $n$ Behebtheid met toetse en eksamens word versag met behulp van deurlopende assessering, en die resultate van sodanige assessering word in ' $\mathrm{n}$ remediërende hoedanigheid aangewend. Voorbereiding vir lewenslange leer word op dié wyse 'n hoë prioriteit.

Onderwyspraktisyns, leerders en ouers sal elkeen hul bepaalde rol moet speel om te verseker dat UGO 'n sukses is. Dit verg uiteraard harde werk en toewyding van diegene wat met onderwys en opleiding gemoeid is. Praktisyns moet daarop ingestel wees om onderrig- en leersituasies vaardig te beplan en te bestuur sodat die beoogde leeruitkomste ten beste realiseer. Vaardigheidsgebaseerde assessering in outentieke omstandighede moet die basis vir betroubare inligting van hoogstaande gehalte vorm.

Die werklike waarde van UGO sal eers beoordeel kan word wanneer die eerste geslag leerders wat aan die UGO-stelsel blootgestel was die arbeidsmark betree of vir hoëronderwysopleiding aanmeld.

\section{- Prof SPT Malan}

Department of Teaching and Training Studies

Faculty of Education

University of Pretoria

\section{INTRODUCTION}

Education is aimed at creating teaching and learning environments that would bring about desired changes in learners, whether to be more knowledgeable, better skilled or to influence their attitudes and values pos $\mathrm{i}$ tively. The essence of teaching and learning is to plan teaching events (contents, strategies, etc) and to ascertain to what extent learners have acquired the intended competences.

Uncertainty about the desired learning outcomes and failure to assess outcomes properly could end in a situation where learners only attained pseudoknowledge, pseudo-skills, pseudo-attitudes and pseudo-values. On completion of their studies these learners are awarded a certificate inherently implying that they have attained certain competences whereas in fact they have not. Disenchantment with education in this regard is obvious - but not a new phenomenon.

Dissatisfaction with education policies and practices have time and again led to initiatives to adjust these practices and systems to meet the needs of learners at the time. However, not all of these turned out to be to their advantage, which gave rise to revised initiatives.

Outcomes-based education [OBE] is currently favoured internationally to promote educational renewal and has been implemented in countries such as Canada, the United States and New Zealand. However, it has already elicited harsh criticism from opponents of the movement (Claassen, 1998; HTTP, 1994). South Africa is introducing its own version of OBE as the basis of Curriculum 2005 (Claassen, 1998; Malan, 1997:73). And, as elsewhere in the world, reactions vary between commendation by its proponents and denouncement by its critics.

Curriculum compilers in South Africa hail OBE as a major paradigm shift in education (Reddy, 1995:13; Department of Education, 1997b; Arjun, 1998). But how original is the OBE dispensation, and does it actually represent a paradigm shift? This article addresses these issues by tracing the roots of OBE and by putting outcomes-based education into perspective.

\section{WHAT IS OUTCOMES-BASED EDUCATION?}

William Spady is regarded as OBE's leading advocate and a few points he makes would suffice. 
Spady (1994:1) defines OBE as a ... comprehensive approach to organizing and operating an education system that is focused on and defined by the successful demonstrations of learning sought from each student. Outcomes are ... clear learning results that we want students to demonstrate at the end of significant learning experiences ... and ... are actions and performances that embody and reflect learner competence in using content, information, ideas, and tools successfully (Spady, 1994:2). Regarding the OBE paradigm, Spady (1994:8) states: ... WHAT and WHETHER students learn successfully is more important than WHEN and HOW they learn something.

Ten key components underlie what is termed the outcomes-based information age paradigm (Spady, 1994:36-40). At issue here is whether it is in fact a new education paradigm.

\section{THE ROOTS OF OBE}

Spady (1994:4) concedes that the world is filled with examples of outcomes-based models, and even that outcomes-based systems go back at least 500 years to the craft guilds of the Middle Ages. The concept of outcomes-based models and systems is therefore not new.

Analysis of educational reform movements in the past reveals prominent features of OBE embedded in the educational approaches described below.

\section{The educational objectives movement}

Incongruity between what is being taught and what is being learned led to the setting of objectives for teachers and learners. McAvoy (1985:28) traced the documented use of objectives in education back as far as 1860 when Spencer in Britain formulated objectives according to a classification of human activities. In 1924 Herbart in Germany stressed the importance of lesson planning and stating objectives to guide teaching activities. In 1949 Tyler gave further impetus to the objectives-oriented movement by stressing the importance of objectives in curriculum design and teaching practices. He listed four questions as the basis for his means end or product-oriented rationale for curriculum design (Tyler, in Arjun, 1998:24):

- What educational objectives should the school aim to achieve?

- How does one select learning experiences that are likely to be useful in attaining these objectives?

- How should learning experiences be organised for effective instruction?

- How would the effectiveness of learning experiences be evaluated?

Tyler's rationale has been used extensively by curriculum practitioners and formed the basis of Wheeler's well-known model of curriculum design which served as the main curriculum design model for several decades (Arjun, 1998:24). The basic OBE phi- losophy for curriculum design is firmly rooted in both Tyler's and Wheeler's models.

During the fifties the work of Bloom (1956) and his coworkers on developing taxonomies for educational objectives became important. These benchmarks were used in the formulation of objectives and the development of criteria to establish whether learners have actually attained acceptable standards compared to the desired learning outcomes. Bloom's (1956) work, particularly in the cognitive domain, remains invaluable for OBE assessment.

After Bloom came Mager whose work was first published in 1962. It ... captured the imagination of many teachers and helped spark off a wave of enthusiasm (and controversy) over objectives (McAvoy, 1985:29). Guidelines (HTTP, 1999) on how to write learning outcomes in OBE closely resemble Mager's (1984:23104) guidelines in terms of expected performance, the conditions under which it is attained, and the standards for assessing quality.

\section{The competency-based movement}

Competency-based education was introduced in America towards the end of the 1960s in reaction to concerns that students are not taught the skills they require in life after school. The same concern has been expressed about education in South Africa.

Competency-based education is based on six critical components (Van der Horst \& McDonald 1997:10-11):

- Explicit learning outcomes with respect to the equired skills and concomitant proficiency (standards for assessment)

- A flexible time frame to master these skills

- A variety of instructional activities to facilitate learning

- Criterion-referenced testing of the required outcomes

- Certification based on demonstrated learning outcomes

- Adaptable programmes to ensure optimum learner guidance

All six components are prominent in the OBE aDproach. Competency-based education also supports the notion that the learner is accountable for his or her own achievements. This is another major tenet underpinning OBE.

\section{The mastery learning movement}

Mastery learning was initially introduced to provide intervention programmes for learners with mild disabilities and those who were at risk in traditional educational settings (Guskey et al, 1995). The authors state that research has confirmed the applicability and value of mastery learning in education to provide learners at all levels with similar, individualised assis tance. With sufficient opportunities and supported by an appropriate learning environment, materials and guidance, most learners would be successful in their 
learning tasks. This notion is also reflected in OBE.

The following main characteristics of mastery learning, also reflected in OBE, apply:

- Ascertaining prerequisite knowledge or skills to attain goals

- A flexible time frame to achieve goals

- Using different media and materials to create enriched teaching / learning contexts

- Formative evaluation to provide feedback for both teaching and learning improvement

\section{Criterion-referenced instruction and assessment}

Criterion-referenced instruction and assessment are well known and form an integral part of all types of performance-based assessment. Mpepo (1998) describes criterion-referenced instruction as a form of mastery learning. It is based on attaining specified objectives and on testing for competence in terms of the criterion stated in the objective. This form of instruction compares a learning outcome or mastery of competencies with a predetermined external standard. Achieving the set standard signifies 'success', and failing to achieve the standard implies 'not yet up to standard', which is followed by remedial intervention.

Criterion-referenced assessment is the preferred mode of assessment in OBE.

\section{Integrating educational approaches}

In lobbying for a change to the traditional approach to teaching and learning, Malan and Jorissen (1990) and Kachelhoffer et al (1992) initiated a three-tiered eclectic framework for curriculum design and teaching / learning practices. The roots of this framework are firmly embedded in all the above-mentioned movements.

The following are the main features of the model and distinctive features of the current OBE approach:

- It is needs-driven. Curricula are designed in terms of the knowledge, skills and attitudes expected from graduates and aim to equip students for lifelong learning.

- It is outcomes-driven. The model has a line that runs from taking cognisance of training needs to setting an aim (purpose) for the programme, goals for syllabus themes, learning outcomes, and finally assessing the learning outcomes in terms of the set learning objectives.

- It has a design-down approach. Linked to needs and the purpose of the programme, learning content is only selected after the desired outcomes have been specified. Content becomes a vehicle to achieve the desired learning outcomes which are aimed at inculcating a basis for life-long leaming

- It specifies outcomes and levels of outcomes. Learning objectives are described in terms of Bloom's (1956) cognitive, affective and psychomotor domains and set according to Mager's (1984) guidelines for formulating objectives.
- The focus shifts from teaching to learning. The model has a student-centred learning approach where lecturers act as facilitators. Study guides help the learners to organise their learning activities, and group work, continuous assessment and self-assessment are major features.

- The framework is holistic in its outcomes focus. Although the learning objectives are aimed at learning at grass-roots level, they are linked to goals and aims at higher levels. Attaining learning objectives is therefore not an end in itself; it provides building blocks for achieving higher-level outcomes.

Table 1 depicts the coherent and holistic relationship between the aim of a programme, its goals, learning objectives and evaluation strategies. The learning objectives are clearly not set for the sake of achieving the objectives per se, but they serve as a means to attaining a programme aim. This same coherent and holistic premise underpins OBE.

\section{OBE IN PERSPECTIVE}

\section{Does OBE represent a paradigm shift?}

It is true that the official version of the curriculum sys tem which OBE is replacing does not meet modern educational needs or expectations. In terms of the life skills learners need and the demands of the workplace, the dominant transmissional approach did not prepare learners adequately for work, further or higher education, or life in general (Reddy, 1995:7-8). This is the same kind of disenchantment that initiated the competency-based movement.

However, does replacing the previous system with an OBE approach represent an educational paradigm shift? Are OBE and its philosophy and practice so different that being promoted as an educational paradigm shift is warranted? The answer to this question is an emphatic no.

According to Mouton (1996:204), a paradigm represents ... a collection of mutually accepted achievements (including the theories, exemplary solutions, predictions and laws). In this sense, a paradigm is primarily a model for onducting normal research When OBE being a paradigm shift is analysed in terms of these constructs, it becomes difficult to support the claim.

There is as yet no collection of mutually accepted achievements in terms of new theories on OBE, there are no exemplary solutions to the challenge of total intellectual and potential development of learners, predictions of the value of OBE have not been proven, and laws validating $\mathrm{OBE}$ as an acceptable practice and construct are not apparent. In other words, no research base to verify the claims of OBE has yet been established and the claim of a major paradigm shift can therefore not be substantiated. 
TABLE 1: THE RELATIONSHIP BETWEEN A PROGRAMME AIM, GOALS, LEARNING OBJECTIVES AND EVALUATION STRATEGIES

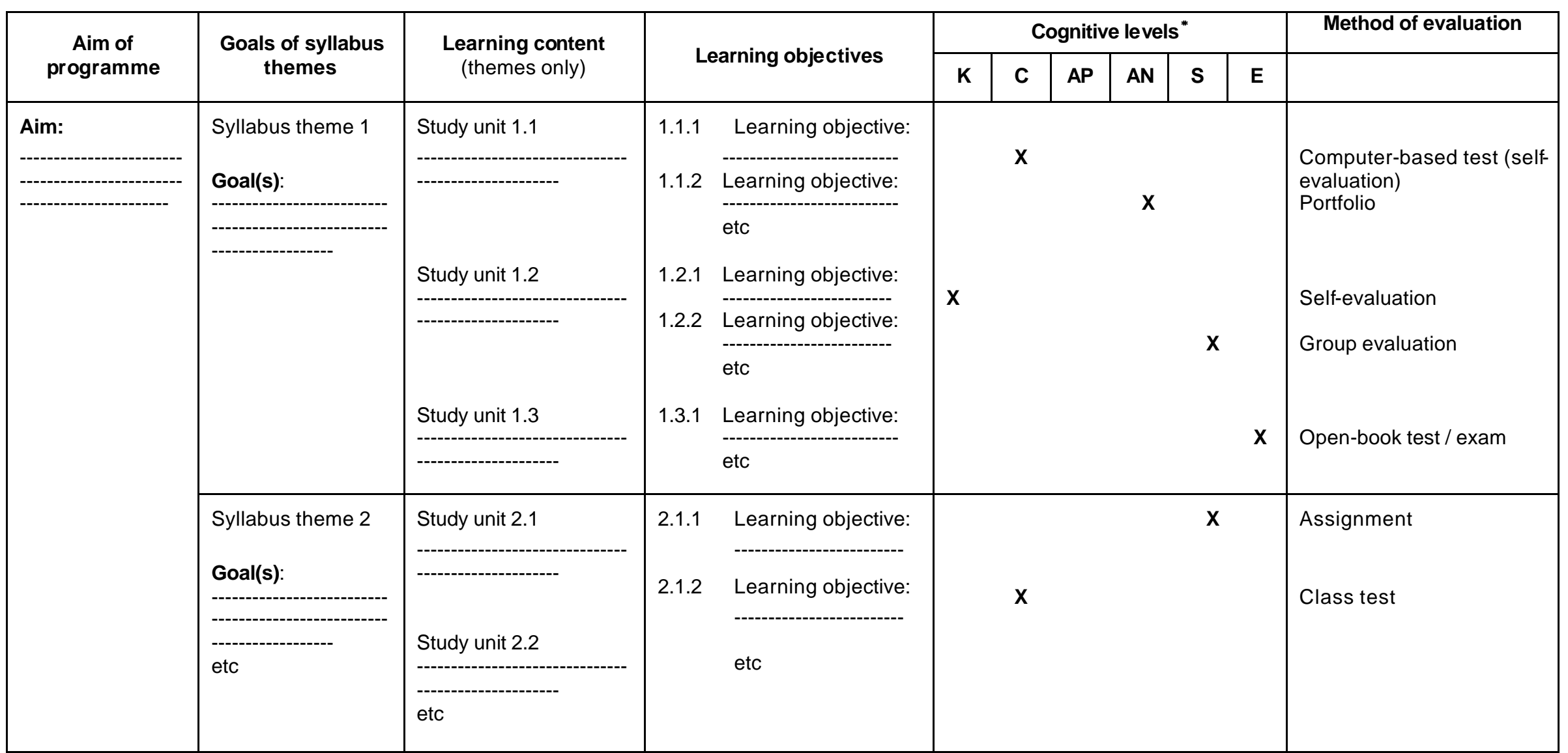


At best OBE may be described as an eclectic philosophy which takes the best from several past educational approaches and incorporating them in a new system that is appropriate to the needs and demands of a new, democratic South Africa. OBE's rationale and practices may be set in a different context for different needs, but its tenets can be clearly traced to older approaches, once also heralded as ideal solutions only to be discarded.

In terms of Kuhn's scheme of scientific revolution, Arjun (1998) also indicates that OBE does not represent a paradigm shift. The author contends that although the science of education is in the midst of a paradigmatic crisis, the means end paradigm of Tyler is still dominant. In fact: Even the proposed new curriculum makes use of this paradigm, which indicates that there is no major paradigm shift (Arjun, 1998:25).

\section{OBE as a transformational approach}

Contrary to the transmissional approach of traditional teaching, Spady (1994:94-98) characterises OBE as a systems transformation approach. Claassen (1998:34) states: OBE is a transformational perspective on the curriculum. It offers a dialogue between learner and the curriculum where the learner interacts with sources of knowledge, reconstructs knowledge, and takes responsibility for his or her own learning outcomes. In the same way the teacher becomes a facilitator in the teaching and learning situation instead of acting as a source of information transferring content to learners. From this viewpoint the transformational character of OBE is influenced by the mastery learning and competency-based education movements.

Spady (1994:36-40) identifies ten key components that underlie OBE as a transformation approach, namely outcomes-defined, expanded opportunities for learners, performance 'credentialing', concept integration, instructional coaching, culminating achievement, 'inclusionary' success, cooperative learning, criterion validation and collaborative structures. Van der Horst \& McDonald (1997:20) redefined these components as characteristics of transformational OBE. When these characteristics are analysed in terms of their foundational roots (as indicated above), the eclectic nature of OBE becomes obvious (see Table 2).

The characteristics of OBE are listed in the first column, and the major roots of each characteristic are indicated in brackets. Transformational aspects that apply to each characteristic appear in the second column (Department of Education, 1997a:7; Van der Horst \& McDonald, 1997:20; Claassen, 1998:35-36).

As indicated in Table 2, it is only in terms of 'Geared towards integrating concepts across the curriculum and learning areas' and 'Based on collaborative structures allowing for democratic inputs from the community' [OBE's sosioconstructivist approach], where no definite roots can for certain be traced to the educational approaches described earlier on. All other characteristics and their accompanying transformational aspects of OBE are firmly based on other educational approaches, reflecting the eclectic nature of the OBE approach.

Claassen (1998:38) notes that proponents of OBE often express a simplistic and one-sided critique of the discredited previous educational model in South $A$ rica. Looking at transformational aspects, it is obvious that many progressive educators, trainers, schools and educational institutions have in any case been adding value to curricula by following a learnercentred and problem -based learning approach.

Was the previous system that bad? One only needs to look at the scientific, economic and political achievements of many people who are products of the old system to appreciate the fact that they excelled despite the much critiqued transmissional mode of teaching. It is a matter of experience to confidently state that a transmissional approach will always have a place in education. In fact, many students and teachers still prefer a transmissional rather than a transformational approach. The reason is simple: it is much easier to teach and to learn within a transmissional framework. However, the broader educational context necessitate an official move to a transformational approach.

\section{Assessment}

The ultimate purpose of assessment is to validate learning outcomes - be it for diagnostic, formative or summative purposes. The role of assessment in OBE is part and parcel of the aims of assessment in all its root models. OBE, however, highlights continuous and criterion-referenced assessment.

OBE aims to assess the competences of learners in their totality. It takes a holistic approach in describing the competence of a learner in terms of knowledge, skills and values, and assessing competence by using a variety of assessment approaches. In fact, the smallest unit of assessment must cover the integrated knowledge, skills and values that apply in practice in a specialised context (Department of Education, 1998:26). This calls for performance-based and authentic assessment strategies against the background of criterion-referenced assessment.

Fraser (1999:16) describes authentic assessment as ... assessment tasks that resemble skills, activities and functions in the real world and in school. Authentic assessment aims at determining competences in contexts that closely resemble situations in which these competences are required. Assessment then becomes a learning experience in which learners are prepared to apply their knowledge, skills and values in an integrated manner.

Assessment of knowledge, values and skills relates to assessing elements in the cognitive, affective and psychomotor learning domains. The taxonomies of Bloom (cognitive domain), Krathwohl (affective $b$ - 
TABLE 2: FEATURES OF A TRANSFORMATIONAL OBE APPROACH

\begin{tabular}{|c|c|}
\hline Characteristics & Transformational aspects \\
\hline $\begin{array}{l}\text { Outcomes define OBE } \\
\text { (Educational objectives, competency-based, mas- } \\
\text { tery learning) }\end{array}$ & $\begin{array}{l}\text { Learners are future-oriented. They are informed about what } \\
\text { they have to achieve and the quality of such achievement. } \\
\text { The process shifts from a content-based input approach to a } \\
\text { competence-based output approach where certification vali- } \\
\text { dates the achieved competences. Attaining outcomes are } \\
\text { not bound by time and calendar constraints. }\end{array}$ \\
\hline $\begin{array}{l}\text { OBE allows for expanding learning opportunities } \\
\text { beyond traditional seat time as learning time } \\
\text { (Competency-based, mastery learning) }\end{array}$ & $\begin{array}{l}\text { The focus is on achieving outcomes according to ability. } \\
\text { Achievement is supported by flexible time frames and not } \\
\text { bound by closed, structured teaching time. Learning pro- } \\
\text { grammes are open-ended and creative. Learners are en- } \\
\text { couraged to form own insights and create own solutions. }\end{array}$ \\
\hline $\begin{array}{l}\text { Based on successful attainment of predetermined } \\
\text { performance outcomes } \\
\text { (Educational objectives, competency-based, mas- } \\
\text { tery learning) }\end{array}$ & $\begin{array}{l}\text { Learners advance through the system when they are able to } \\
\text { demonstrate attainment of the desired outcomes. They are } \\
\text { assessed continuously and facilitated to attain these desired } \\
\text { outcomes. }\end{array}$ \\
\hline $\begin{array}{l}\text { Aided by instructional guidance where learners } \\
\text { receive continuous learning support } \\
\text { (Competency-based, mastery learning) }\end{array}$ & $\begin{array}{l}\text { Teaching is no longer aimed at covering the curriculum } \\
\text { (content-driven), but instead at learners discovering new } \\
\text { knowledge, skills and attitudes by reconstructing content for } \\
\text { themselves with creative guidance by the teacher. }\end{array}$ \\
\hline $\begin{array}{l}\text { Builds on a culminating achievement of desired } \\
\text { learning outcomes } \\
\text { (Competency-based, mastery learning) }\end{array}$ & $\begin{array}{l}\text { Attaining outcomes provides the foundation for applying ac- } \\
\text { quired knowledge, skills and attitudes, leading to the attain- } \\
\text { ment of ultimate desired outcomes. }\end{array}$ \\
\hline $\begin{array}{l}\text { Geared towards integrating concepts across the } \\
\text { curriculum and learning areas } \\
\text { (New. Not a main feature of previous ap- } \\
\text { proaches) }\end{array}$ & $\begin{array}{l}\text { The focus shifts from atomistic mastering of content as an } \\
\text { end in itself to using content as a vehicle towards holistic } \\
\text { conceptual frameworks across the curriculum. }\end{array}$ \\
\hline $\begin{array}{l}\text { Success-oriented allowing for individual learners } \\
\text { to succeed according to own abilities. } \\
\text { (Mastery learning) }\end{array}$ & $\begin{array}{l}\text { Capacity building according to learners' own abilities is para- } \\
\text { mount. The selection-oriented approach of pass or fail is } \\
\text { reduced. All learners progress according to ability. }\end{array}$ \\
\hline $\begin{array}{l}\text { OBE is characterised by cooperative learning } \\
\text { (Not a main feature in mentioned approaches, but } \\
\text { cooperative or collaborative learning as such is } \\
\text { not new (also see Johnson et al, 1998:28-29)) }\end{array}$ & $\begin{array}{l}\text { Individual contest and competition decrease and teamwork } \\
\text { is encouraged. }\end{array}$ \\
\hline $\begin{array}{l}\text { Attainment of outcomes is confirmed by criterion } \\
\text { assessment } \\
\text { (Competency-based, with roots in criterion- } \\
\text { referenced instruction) }\end{array}$ & $\begin{array}{l}\text { The emphasis shifts from attaining a pass mark or distinction } \\
\text { to a demonstration of competence at predetermined levels. } \\
\text { Criterion-referenced assessment focuses on assessing out- } \\
\text { comes and not grading as such. }\end{array}$ \\
\hline $\begin{array}{l}\text { Based on collaborative structures allowing for de- } \\
\text { mocratic input from the community } \\
\text { (New. Not a main feature of previous ap- } \\
\text { proaches) }\end{array}$ & $\begin{array}{l}\text { The OBE curriculum is open to the environment. The cur- } \\
\text { riculum is democratised and is the result of negotiation, not } \\
\text { fixed and changeable (ie a sosioconstructivist approach). }\end{array}$ \\
\hline
\end{tabular}

The 'new paradigm' of outcomes-based education in perspective 
main) and Harrow (psychomotor domain) remain invaluable frameworks for assessing acquired knowledge, skills and values in terms of OBE (Van der Horst \& McDonald, 1997:176-178).

The Department of Education's viewpoint is that the smallest unit of assessment must include the integration of knowledge, skills and values. Within this context performance-based authentic assessment strategies are pivotal in assessing learning and critical cross-field outcomes.

\section{IN CONCLUSION}

OBE is firmly rooted in past educational approaches and does not represent a paradigm shift as advocated by OBE proponents. At best OBE can be described as an eclectic educational philosophy taking the best from previous approaches and framing it in a new visionary system that is appropriate to the needs and demands of a democratic South Africa. As in the case of previously highly publicised - but at some stage discredited - educational approaches, only time will reveal the true value of OBE. With a socioconstructivist base that makes allowances for stakeholder input, OBE may become a living educational model, adapting to new demands and needs.

There are many positive sides to OBE, as its transformational approach indicates. It brings about a rational focus on education as a means to an end and not an end in itself. It forces uncoordinated and laissez-faire educational planning, managing and teaching practices into the background and introduces strategic educational planning that is aimed at achieving results.

Educational practitioners, learners and parents all have to play their particular roles to ensure that OBE works. Learners have to assume greater responsibility and actively participate in the learning process. And, hopefully, this will contribute to restoring a culture of learning in many schools. On the other hand, implementing OBE in all these environments poses a major challenge in terms of its being accepted. After all, a transmissional approach is easier on educators and students alike.

Educational practitioners have to become more attuned to planning and managing learning environments and must be committed to the ideal of valid and reliable assessment. Parents (the larger community for that matter) have to exercise their democratic right to ensure that the quality of education remains unquestionable and that learners are properly prepared for life after school or higher-education studies.

Concerned groups in the USA took up this challenge and it caused the downfall of the OBE paradigm in the United States. In his most recent book, Spady (1997:3) concedes: What seemed to be an impending systemic paradigm shift in thinking, policy, and practice toward educational change in the early '90s, lies largely lost under an avalanche of political reac- tion and reforms that tinker rather than reform. (Refer to his Chapter 3, What went wrong, for an overview of resistance and reactions to $\mathrm{OBE}$.)

What is going to happen in South Africa? If OBE survives, the academic quality of the first entrants of the OBE cohort into the workplace and higher-education sectors will not only reveal the assumed benefits and values of $\mathrm{OBE}$, but its shortcomings as well.

\section{REFERENCES}

ARJUN, P. 1998. An evaluation of the proposed new curricula for schools in relation to Kuhn's conception of paradigms and paradigm shifts. South African Journal of Higher Educ ation 12(1):20-26.

BLOOM, BS (ed). 1956. Taxonomy of educational objectives. Handbook 1. Cognitive domain. New York. McKay. CLAASSEN, C. 1998. Outcomes-based education: some insights from complexity theory. South African Journal of Higher Education 12(2):34-40.

DEPARTMENT OF EDUCATION. 1997a. Information brochure: Curriculum 2005. Lifelong learning for the $21^{\text {st }}$ century. Pretoria.

DEPARTMENT OF EDUCATION. 1997b. Call for com ments. Government Notice no 18051. Pretoria. Government Printer.

DEPARTMENT OF EDUCATION. 1998. Norms and standards for educators. Pretoria. Government Printer.

FRASER, WJ. 1999. The foundations of continuous assessment: its link to performancebased, authentic, competence-based and outcomes-based assessment. University of Pretoria. Unpublished article.

GUSKEY, TR, PASSARO, PD \& WHEELER, W. 1995. Mastery learning in the regular classroom. Teaching Exceptional Children 27(2):15-18.

HTTP. 1994. http.//www.i2i.org/SuptDocs/lssuPprs/ IsOBEduc.htm.

HTTP. 1999. http.//www.up.ac.za/announce/intranet/saqa/ saqagdls.html\#LEARNING.

JOHNSON, DW, JOHNSON, RT \& SMITH, KA. 1998. Cooperative learning returns to college. Change July / August:27-35.

KACHELHOFFER, PM, MALAN, SPT \& KNOETZE, JG. 1992. Riglyne vir kurrikulumontwikkeling. In Malan, SPT \& Du Toit, PH (reds). Suksesvolle onderrig. Riglyne vir dosente, onderwysers en opleiers. Pretoria. Academica.

MAGER, RF. 1984. Preparing instructional objectives. 2nd ed. Belmont, California. David S Lake Publishers.

MALAN, B. 1997. Excellence through outcomes. Cape Town. Juta.

MALAN, SPT \& JORISSEN, HW. 1990. 'n Kurrikulumontwikkelingsmodel as kriteriumraamwerk vir formatiewe kurrikulumevaluering. Suid-Afrikaanse Tydskrif vir Hoër Onderwys (Spesiale uitgawe):71-79.

McAVOY, BR. 1985. How to choose and use educational objectives. Medical Teacher 71:27-35.

MOUTON, J. 1996. Understanding social research. Pretoria. Van Schaik.

MPEPO, CC. 1998. Criterion-referenced instruction (CRI) as a form of mastery learning. Educamus 34(3):8-9.

REDDY, K. 1995. The inclusion of technology as a subject in the national curriculum. A significant paradigm shift for education in South Africa. MEd thesis. University of Pretoria.

SPADY, WG. 1994. Outcome-based education. Critical issues and answers. Arlington. American Association of School Administrators.

SPADY, WG. 1997. Paradigm lost. Reclaiming America's educational future. Arlington. American Association of School Administrators.

VAN DER HORST, H \& MCDONALD, R. 1997. OBE. A teacher's manual. Pretoria. Kagiso. 